CUADERNOS DE ESTUDIOS GALLEGOS, LIX Núm. 125 (enero-diciembre 2012), págs. 39-63

ISSN: 0210-847 X

DOI: $10.3989 /$ ceg.2012.125.02

\title{
IMAGEM E TERRITÓRIOS DAS ELITES BURGUESAS GALEGAS: A ESCULTURA FUNERÁRIA (SÉCULOS XIV-XV)*
}

\author{
Matías García RodríGuez \\ Universidade de Santiago de Compostela
}

\begin{abstract}
* Este artigo foi realizado ao abeiro das práticas do Consello Social da USC realizadas no Instituto de Estudos Galegos "Padre Sarmiento" (CSIC - Xunta de Galicia) entre o 3 de Março e o 15 de Julho de 2011, no marco do projeto de investigação "A cultura dos pazos en Galicia: o Pazo de Tovar" (código 10SEC606033PR), Programa Sectorial de Investigación Aplicada do Plan Galego de Investigación, Desenvolvemento e Innovación Tecnolóxica da Dirección Xeral de Investigación, Desenvolvemento e Innovación da Consellería de Economía e Industria (Xunta de Galicia); investigador principal: Antón M. Pazos. Tanto pelo que se refere a este texto, como às práticas e à minha primeira publicação, a minha devida para com Carlos A. González Paz (IEGPS) é total: obrigado. Igualmente, querería agradecer ao professor David Chao Castro (USC), a amável cessão da imagem da lauda de Rui Lopes.
\end{abstract}




\title{
IMAGEM E TERRITÓRIOS DAS ELITES BURGUESAS GALEGAS: A ESCULTURA FUNERÁRIA (SÉCULOS XIV-XV)
}

\begin{abstract}
RESUMO
Do mesmo jeito que no âmbito da nobreza se assiste a um claro aumento do número de sepulcros isentos e baixo arcossólio durante os séculos XIV e XV, também no das elites burguesas corroboramos um incremento na decoração dos seus enterramentos. De feito, este fenômeno de emulação e/ou homologação perante a fidalguia urbanizada será o mais característico no seio desta burguesia enriquecida, parte essencial das oligarquias municipais. Analisaremos alguns aspeitos desta representação de classe, nomeadamente em relação à escultura funerária, desde um enfoque de crítica da ideologia e teoria lacaniana, em especial no que respeita a um caso paradigmático como é o do sepulcro de Joám do Campo em São Domingos de Bonaval.
\end{abstract}

PalaVRas Chave: São Domingos de Bonaval, identificação imaginária / simbólica, ideologia, Lacan, representação, Žižek.

\section{IMAGEN Y TERRITORIOS DE LAS ÉLITES BURGUESAS GALLEGAS: LA ESCULTURA FUNERARIA (SIGLOS XIV-XV)}

\section{RESUMEN}

De la misma manera en que en el ámbito de la nobleza se asiste a un claro aumento del número de sepulcros exentos y bajo arcosolio durante los siglos XIV y XV, también en el de las élites burguesas corroboramos un incremento en la decoración de sus enterramientos. De hecho, este fenómeno de emulación y/o homologación a respecto de la hidalguía urbanizada será el más característico en el seno de esta burguesía enriquecida, parte esencial de las oligarquías municipales. Analizaremos algunos aspectos de esta representación de clase, especialmente en relación a la escultura funeraria, y desde un enfoque de crítica de la ideología y teoría lacaniana, en especial por lo que respecta a un caso paradigmático como es el del sepulcro de Joám do Campo en São Domingos de Bonaval.

PAlABRAS Clave: São Domingos de Bonaval, identificación imaginaria / simbólica, ideología, Lacan, representación, Žižek.

\section{IMAGE AND TERRITORIES OF THE GALICIAN BOURGEOIS ELITES: FUNERARY SCULPTURE $\left(14^{\mathrm{TH}}-15^{\mathrm{TH}}\right.$ CENTURIES)}

\section{AbSTRACT}

As well as a clear rising of the sumptuous tombs is asserted during the $14^{\text {th }}$ and $15^{\text {th }}$ centuries within the sphere of nobility, also an increase in the decoration of graves took place in that of the bourgeois elites. In fact, this phenomenon of emulation with regard to the urbanized fidalguia will be the most characteristic one of this enriched bourgeoisie, which is an essential part of the municipal oligarchies. We will analyse some aspects of this class representation, especially concerning funerary sculpture, and from a perspective of critique of ideology and lacanian theory, especially in what refers to a paradigmatic example, the tomb of Joám do Campo in São Domingos de Bonaval.

KEY WORDS: São Domingos de Bonaval, imaginary / symbolic identification, ideology, Lacan, representation, Žižek. 
Recibido/Received: 09/04/2012

Aceptado/Accepted: 14/08/2012

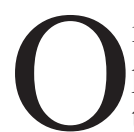

incremento da suntuosidade e relevância geral da escultura funerária para a nova nobreza trastamarista é sem dúvida um fenômeno bem estudado pela historiografia galega. As elites burguesas, agora ao carão da fidalguia mais urbanizada no âmbito das oligarquias municipais, tomaram boa nota dele e cedo começaram a operar no seu seio toda uma série de processos de emulação, tanto a nível econômico e político como no seu correlato representacional (o nosso objeto de estudo), que abordaremos desde um ponto de vista de crítica da ideologia e privilegiando o exemplo de São Domingos de Bonaval, onde se topa o problemático sepulcro de Joám do Campo.

\section{JE SAIS BIEN, MAIS QUAND MÊME... UMA METODOLOGIA}

Uma olhada rápida levaria-nos a concluir que os resultados da crítica da ideologia nos estudos de história da arte tenhem dado resultados muito pobres ${ }^{1}$. Resulta pertinente, já que logo, o seu uso? Alguma nota sobre o próprio termo "ideologia" e o seu devir recente, útil entre tanta confusão, pode ilustrar-nos sobre do oportuno que pode resultar este enfoque que hoje, ainda cheirando tanto a humidade, a velho, em geografias como a nossa, domina os mais ativos campos de batalha da filosofia, teoria de gênero, estudos pós-coloniais, etc. ${ }^{2}$ Que teóricos tão dispares como Judith Butler, Simon Critchley, Peter Singer, Göran Therborn, Cornel West ou Alenka Zupančič, por citar só alguns dos mais relevantes, dedicaram na última década muitos dos seus esforços neste senso, cara diferentes jeitos de crítica da ideologia, merece quando menos uma olhada atenta.

\footnotetext{
${ }^{1}$ Se bem, numa segunda olhada, veríamos como em realidade não foi apenas usado com um senso minimamente concreto nesta disciplina, agás em minoritários estudos, pelo demais muito recentes. A chamada história social da arte baseou-se em termos gerais sobre dum enfoque culturalista (e, pelo tanto, não propriamente ideológico), e o mesmo poderíamos dizer tanto do neo-formalismo dessa suposta vanguarda que são os "estudos visuais" como da ainda prestigiosa escola semiótica. 2 Entre a extensíssima, e ainda em vigorosa construção, bibliografia, uma excepcional introdução será Terry EAgLeton, Ideology. An Introduction, London / New York, Verso, 1998 (1991).
} 
Os problemas, em todo caso, começam já a nível semântico. O termo "ideologia", de hercúlea etimologia, foi usado para descrever virtualmente qualquer cousa: doutrinas orientadas à ação (ou inação), deformação da realidade social que legitima um domínio dado, relação ilusória a respeito das condições de produção, etc. Seguindo a Žižek, por certo um dos teóricos da crítica

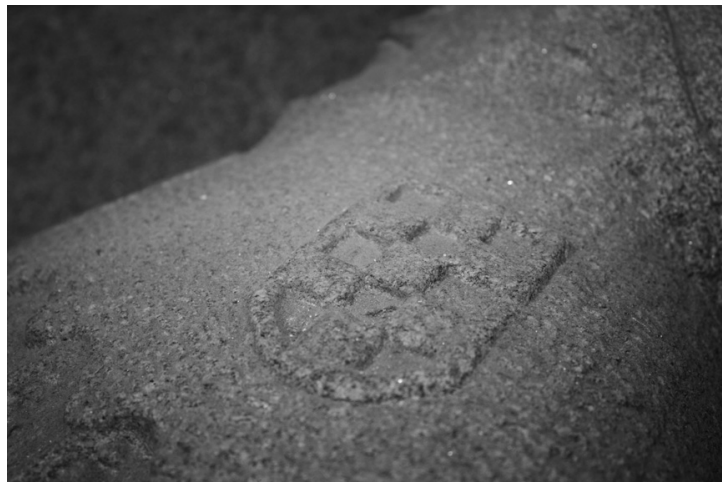

Fig. 1

Escudo dos do Campo sobre o jacente do sepulcro de Joám do Campo (São Domingos de Bonaval) da ideologia mais relevantes dos últimos vinte anos, poderíamos resumir esta confusa polissemia em função dos três níveis que Hegel distinguia em relação à religião: doutrina, crença e ritual; assim, contemplou-se uma ideologia como complexo de ideias (teorias, argumentos, convicções), como uma manifestação externa desses complexos (o Estado e os seus aparelhos) e, finalmente, como essa "ideologia" que opera espontaneamente no núcleo da "realidade" social". Correspondente a cada nível, desenvolveram-se diferentes jeitos de crítica.

Num primeiro momento, a crítica operou por uma leitura de "sintomas", das tendências inconfessadas do discurso, os seus espaços em branco, os seus deslices. Além de simplista, o que leituras deste tipo ignoram é que a noção mesma dum aceso à realidade sem a estruturação de dispositivos discursivos, duma conjunção de poderes, é per se um exemplo canônico de ideologia. O paradoxo, imediato e constante, é evidente: o afastamento daquilo que experimentamos como ideologia é o ideológico por excelência ${ }^{4}$; estamos já no núcleo do nosso problema.

A análise do discurso leva-lhe, como em tantas ocasiões, vários corpos de vantagem à teoria política. Já em 1980, Ducrot desenvolvia (sem falar de "ide-

\footnotetext{
3 Slavoj ŽıžeK, "The Spectre of Ideology", em Slavoj ŽıžEK (ed.), Mapping Ideology, London / New York, Verso, 1994, págs. 9-10.

${ }^{4}$ Desde este ponto de vista, não cai toda "crítica da ideologia" na mais pura ingenuidade ideológica?; "Ideology: what is repeated and consistent (by this last adjective, it is excluded from the order of the signifier). So ideological analysis (or counter-ideology) need merely be repeated and consistent (by proclaiming on the spot its validity, by a gesture of pure clearance) in order to become, itself, an ideological object" (Roland BARTHES, Roland Barthes by Roland Barthes, tr. Richard HowARD, Berkeley, California University Press, 1994 -1975-, pág. 104).
} 
ologia") uma teoria da argumentação baseada na impossibilidade de qualquer contido discursivo neutral; toda designação é sempre parte dalgum esquema argumentativo, é de facto um gesto argumentativo reificado sobre da base de topoi que se naturalizam na medida em que os usamos de jeito automático, digamos "inconsciente" . De feito, trinta anos antes Barthes falava já nas Mitologias duma naturalização da ordem simbólica como percepção que reifica os resultados dos procedimentos discursivos em propriedades da "cousa em sim".

A implicação fundamental, sinalada já por todos estes teóricos, é o abandono da teoria clássica "representacionalista" da ideologia, que per se não têm propriamente nada que ver com uma "ilu-

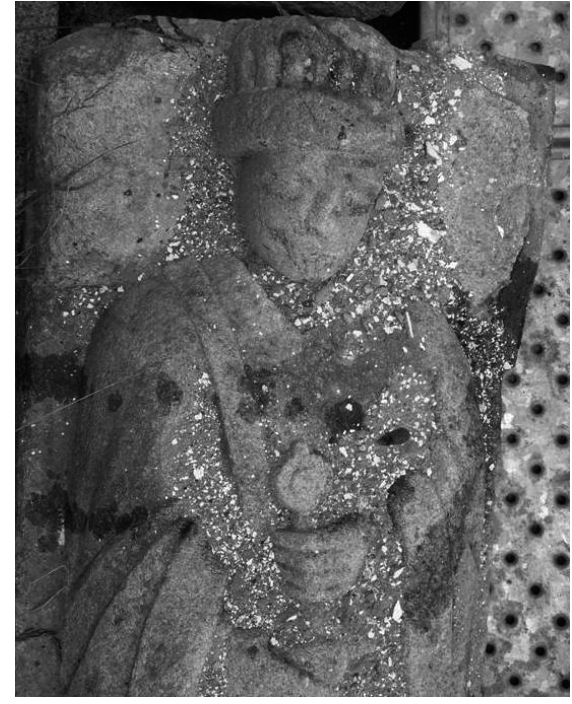

Fig. 2

Lauda de Rui Lopes, notário (São Pedro de Melide). Fotografía de David Chao Castro

(USC) são", uma representação falsa ou falseada, desenfocada, dum determinado contido social objectivo ${ }^{6}$. O contido afirmado como tal é irrelevante em termos ideológicos, o que importa é como este contido se relaciona com a própria posição subjetiva suposta pelo seu próprio processo de enunciação, isto é, o jeito em que um enunciado resulta funcional a respeito dum domínio social dado de jeito não explícito?

\footnotetext{
5 Slavoj Žı̌̌EK, “The Spectre of Ideology”..., págs. 18-9; Oswald Ducrot, Le dire et le dit, Paris, Minuit, 1980.

6 "To put it succinctly: a political standpoint can be quite accurate ('true') as to its objective content, yet thoroughly ideological; and, vice versa, the idea that a political standpoint gives of its social content can prove totally wrong, yet there is absolutely nothing 'ideological' about it" (Slavoj Žı̌ž, "The Spectre of Ideology...", pág. 7). O próprio Marx, nas suas obras de juventude, longe ainda da sua teoria sobre o fetichismo da mercadoria, caiu nesta trampa da oposição entre a quimera ideológica e o estudo da "realidade"; a ideologia era para ele pura ilusão, sonho. Marx estava a adotar uma concepção de ilusão que alude (de jeito falseado) à realidade que o conectava tanto com o mecanicismo do século XVII (Deus é unha representação imaginária do Rei real) como com a "hermenêutica" de Feuerbach (Deus é a essência do Homem real); veja-se Louis Althusser, "Ideology and Ideological State Apparatuses (Notes towards na Investigation)”, em Slavoj Ž Ž̌̌EK (ed.), Mapping Ideology, London / New York, Verso, 1994, pág. 123 (original em Louis AlthusSER, "Ideologie et appareils idéologiques d'État (notes pour une recherche)", em La Pensée, 151 -1970-).

${ }^{7}$ Os "feitos" não falam, uma rede discursiva os fai-nos falar. O que "vemos com os nossos próprios olhos", vemo-lo contra dum fundo pré-construído discursivamente; veja-se Michel PÊcheux, "The
} 
Estas inocentes "ideias", estes discursos, manifestam-se a todos os níveis da nossa vida cotiá, no comportamento econômico, legal, sexual, e as mais das vezes de jeito espontâneo. Estes discursos, quando acadam o nível da representação plástica, constituem segundo o enfoque da crítica da ideologia o objecto de estudo e o senso mesmo do historiador da arte (sendo esta uma disciplina não isolada, senão parte do rizoma-História $)^{9}$. No caso baixo-medieval, um jeito privilegiado de representação é o constituído pela escultura funerária, uma escultura que nos falará à sua vez de muitos outros aspeitos desta burguesia e fidalguia, da sua vida e roles. Para abordar tal estudo, precisemos em primeiro lugar estes termos.

\section{El sSE QUer MUYT' A SEU PODER ONRRAR. Algumas linhas de DEMARCAÇÃo}

Nos séculos finais da Idade Media, assistimos a um câmbio muito relevante na estrutura econômica das cidades, como é o crescente papel da possessão de riqueza em relação às correntes comerciais. Estas correntes aparecem no momento mesmo em que o faz a cidade, mas o papel destas como centro reitor do mercado fora medrando, até ser algo já inequívoco para os séculos XIV e XV. Além da expansão do uso da moeda, este fenômeno propiciará uma transgressão a nível social que seria impensável no contexto da economia rural, e que nos permite diferenciar entre a burguesia a um pequeno grupo, de limites imprecisos e sem caráter juridicamente diferenciado, composto na sua maior parte por merca-

\footnotetext{
Mechanism of Ideological (Mis)recognition”, em Slavoj Žı̌̌̌K (ed.), Mapping Ideology, London / New York, Verso, 1994, págs. 141-51 (original em Michel PÊCHeux, Les vérités de La Palice. Linguistique, sémantique, philosophie, Paris, Maspero, 1975). Do mesmo jeito, para Deleuze, toda produção de senso é entendida como labor eminentemente político, como construção dumas determinadas condições de enunciabilidade e visibilidade; de jeito muito semelhante ao de Laclau, para ele senso e acontecimento são assimiláveis, mais não tudo acontecimento se carga de senso; o que faz visível áquele são as forças que se apoderam do pensar, que obrigam a pensar numa determinada direção: o Poder; veja-se Gilles Deleuze, Différence et répétition, Paris, Pág.U.F., (1969); Logique du sens, Paris, Minuit, 1969; Critique et clinique, Paris, Minuit, 1993.

8 Althusser, no seu artigo clássico sobre os Aparelhos Ideológicos do Estado, toma a Pascal ("ageonlha-te, move os teus beiços em oração, e crerás") e aponta como as "ideias" dum sujeito são em realidade "his material actions inserted into material practices governed by material rituals which are themselves defined by the material ideological apparatus from which derive the ideas of that subject" (Louis Althusser, "Ideology and Ideological State Apparatuses...", pág. 127). Por outra parte, o feito de que os aparelhos althusserianos, os micro-poderes foucaultianos ou a sociedade de controlo deleuziana amossaram como o poder real passa por alto a ideologia "com maiúsculas" e se inscreve diretamente no corpo, explica em parte que os autores pós-modernos evitem pelo geral este termo.

${ }^{9}$ Este é propriamente, de feito, o objeto de toda crítica ideológica, já que "ideology is less a matter of the inherent linguistic properties of a pronouncement than a question of who is saying what to whom for what purposes" (Terry EAGLETon, Ideology..., pág. 9; a cursiva é nossa).
} 
dores, mais também por profissionais de ofícios liberais (notários, procuradores, escribas, etc.) e mesmo por artesãos especializados em produções de alto valor engadido (como os ourives).

No seio desta elite burguesa, e a pesares de serem um grupo instável, cambiante, difícil de apreender, a existência duma certa autoconsciência de grupo fará ato de presença, e medrará a medida que o faga o seu poder. Assistimos a este fenômeno sobre todo no novo cenário no que estes burgueses enriquecidos se movem: as oligarquias municipais.

Longe de serem uma abstração, estas oligarquias eram uma realidade bem palpável nas vilas do outono medieval galego, regidas de fato por estes grupos, nas que junto a esta "alta burguesia" se dão cita as famílias fidalgas mais urbanizadas. A debilidade que o sistema de rendas agrarias começara a amossar, traduzira-se numa grande instabilidade para aqueles que baseavam nele o seu sistema de vida, os fidalgos ${ }^{10}$. Isto explica que, ainda que continuem a contar com um suporte econômico relativamente sólido tanto na produção agraria como na propriedade imobiliária urbana, observemos uma clara tendência a se achegar ao mundo do comércio e os negócios ${ }^{11}$.

$\mathrm{O}$ achegamento destas famílias aos burgueses enriquecidos beneficiará também a estes, desejosos de acadar uma condição fidalga que reportasse não já só um câmbio de status sociojurídico senão, e sobre todo, a exençao tributária para eles e para a sua descendência (já "fidalga"). Assim, uma vez ambos sectores, por comum interesse, começem a se entrelaçar, observaremos imediatamente um forte processo de homologação interna, traduzido na maior parte dos casos numa emulação burguesa do jeito de vida e representação da fidalguia, um "afidalgamento" a todos os níveis:

a) no econômico, uma vez começam estas oligarquias híbridas a se fazer com o controlo das estruturas de poder municipal, desenvolvem desseguido uma política encaminhada ao favorecimento de mercadores e rentistas fronte às classes produtoras (reproduzindo, pelo tanto, a sua prevalência social), o qual tomará corpo nas normas reguladoras do mercado, na gestão da fazenda, na regulamen-

\footnotetext{
${ }^{10}$ A sua situação fora empiorando progressivamente durante o século XIV, mas já no XIII a nobreza laica galega perdera parte do seu prestígio social, fundamentalmente devido a esse deterioro na sua base econômica, a propriedade da terra, medrando assim o problema da diminuição das rendas que a fidalguia obtinha dessas já escassas terras que possuíam por mor das catástrofes que predominaram nesses anos.

${ }^{11}$ Este mesmo declive será o que explique também uma tendência a se achegar à Igreja, vizinho poderoso, já fosse mediante doações e mandas testamentárias, já fosse ingressando diretamente nas suas ringleiras (Anselmo López CARREIRA, A cidade de Ourense no século XV. Sociedade urbana na Galicia baixomedieval, Ourense, Deputación Provincial de Ourense, 1998, pág. 329).
} 
tação dos ofícios, etc. Cedo, o seu caráter gregário verá-se acentuado até o ponto mesmo de se situar às vezes contra os próprios comerciantes ${ }^{12}$.

b) socialmente, já que logo, o resultado vai ser o desenvolvimento de gerações "híbridas", mistas. Em última instância, a fusão via matrimonial de ambos sectores sociais desembocará na criação de novas estirpes fidalgas.

c) as estruturas parentelares destes burgueses afidalgados (e, progressivamente, "enfidalgados"), acomodaram-se às das famílias fidalgas, e mesmo ao seu caráter territorial, nomeadamente em relação à adquisição de propriedade (e já não só urbana senão agora também fora das muralhas). Do mesmo jeito, emularão à baixa nobreza na procura da arrecadação de rendas públicas (a burguesia territorializa-se ao tempo que a fidalguia se desterritorializa $)^{13}$.

Este processo trairá também consigo a assunção da estrutura de linhagens, para o século XIV já plenamente consolidada na $\mathrm{Galiza}^{14}$ e garante duma funcionalidade plena do sistema da herdança (a descendência transmite agora uma determinada condição social juridicamente perfilada e, ademais, a consabida muda do sistema cognatício pelo agnatício despeja toda dúvida perante a transmissão indivisa do patrimônio ${ }^{15}$ ). Assumirão igualmente a rede clientelar que caracterizava a estas famílias fidalgas.

\footnotetext{
12 Pensamos, por exemplo, na Pontevedra de 1492, na que os mareantes decidem enfrontarem-se aos nobres e grandes mercadores introduzidos no concelho, demandando-os ante o arcebispo Fonseca; estes, proprietários das terras nas proximidades da vila, tentavam evitá-la entrada de vinho ourensão para vender assim o seu, ao tempo que os mareantes pretendiam precisamente mercá-lo fora para a exportação, alegando trás das medidas tomadas pelo concelho "ynjustas ordenanças por el bien y ynteres pecunial de diez o doçe onbres herederos de viñas, siendo como eran los mismos regidores" (José ARMAS CASTRO, "Una familia de mercaderes pontevedreses a finales de la Edad Media: los Cruu", em Cuadernos de Estudios Gallegos, 101 -1986-, págs. 131-2; veja-se também José Miguel Andrade Cernadas e Francisco Javier Pérez Rodríguez, Galicia Medieval, t. III de Historia de Galicia, Oleiros, Vía Láctea, 1995, pág. 255).

${ }^{13}$ Este tema foi recentemente abordado no congresso Mercaderes y hombres de negocio en la Edad Media de la Corona de Castilla (Valladolid, 26-27 de Setembro de 2011), em especial referência ao caso pontevedrês, na palestra a cargo de Amparo Rubio Martínez, "Mercaderes y financieros en el arrendamiento de rentas reales en la Galicia del siglo XV".

14 Assistimos aos seus primeiros passos já na segunda metade do século XIII, mas em todo caso não deixa de ser um fenômeno retardatário a respeito da área castelã (veja-se Isabel BECEIRo PITA e Ricardo Córdoba de la Llave, Parentesco, poder y mentalidad. La nobleza castellana siglos XII$X V$, Madrid, CSIC, 1990). Sobre as linhagens galegas, veja-se como introdução, Eduardo PARDO DE Guevara y Valdés, "De las viejas estirpes a las nuevas hidalguías: el entramado nobiliario gallego al fin de la Edad Media", Nalgures, 3 (2006), págs. 263-78.

${ }^{15}$ Isto deriva também em câmbios dentro da própria relação do grupo familiar, já que, dada a transmissão hereditária por parte do cabeça de família e a primazia da linha masculina, assistimos a um reforçamento claro do autoritarismo patriarcal e, consequentemente, a uma maior supeditação da mulher (como também dos filhos, por outra parte). A mulher vê impedida a sua mobilidade ainda mais, e a sua limitação na participação na herdança não lhe permite mais que duas opções: contrair
} 
d) a nível institucional, estas oligarquias vão-se estabelecendo sobre todo durante o século XIV; a medida que isto sucede, o processo de homologação interna e endogamia se acentua. Instalados em cargos vitalícios, a rede estabilizase e diferença-se, contrai-se, fecha-se. Para o século XV, assistimos já a uma patrimonialização dos ofícios municipais.

e) desde um ponto de vista sócio-simbólico, e a medida que o poder econômico (e, consequentemente, social) se reviste deste caráter patrimonial, e dado que o nexo entre o individuo e o grupo familiar é o garante do status daquele, desenvolve-se uma consciência genealógica.

f) o discurso plástico desta burguesia enriquecida põe de manifesto todos estes fenômenos. Em vida, escudos, possessões, e ainda vestimenta, rituais, cerimonias, procissões e festas representarão a sua nova posição social hegemônica dum jeito claramente homologável ao dessa fidalguia com a que compartilham o poder ${ }^{16}$; para além da morte, esse papel corresponderá à escultura funerária. A medida, como já temos dito, que a consciência genealógica se fortalece após da estabilização da linhagem e a patrimonialização do poder municipal, este discurso se reforça à sua vez, e nele observamos fundamentalmente três fenômenos:

f.1) a casa como instituição socioeconômica.- Ponto de referência do grupo familiar, a casa com torre, o paço, etc., é agora o centro simbólico e o suporte

matrimônio ou ingressar num mosteiro (María del Carmen Pallares Méndez e Ermelindo Portela Silva, O encadramento social e a loita polo poder, em Xosé Ramón Barreiro Fernández e Ramón Villares Paz (coords.): A Gran Historia de Galicia, A Corunha, La Voz de Galicia, 2007, t. V, De Xelmírez aos Irmandiños. A Galicia feudal (séculos XII-XV), vol. 2, págs. 36, 39; veja-se também María del Carmen Pallares Méndez, A vida das mulleres na Galicia Medieval (1100-1500), Santiago de Compostela, Universidade de Santiago de Compostela, 1993, pág. 140; María del Carmen Pallares Méndez e Ermelindo Portela Silva, "Los mozos nobles: grandes hombres, si fueran hijos solos", em Revista d'historia medieval, 5 -1994-, págs. 57-60).

16 "Suer Fernándiz, si veja plazer, / veste-se ben, a todo seu poder; / e outra cousa lhe vejo fazer, I que fazen outros poucos no reinado: / sempre en verão lhe vejo trager, / e no inverno, çapato dourado. / El se veste e se calça mui ben; / en esto mete el o mais do que ten [...]" "“Suer Fernándiz, si veja placer" -fragm.-, cantiga de Fernám Rodrigues Redondo, apud Mercedes Brea LóPeZ (coord.), Lírica Profana Galego-Portuguesa. Corpus completo das cantigas medievais, con estudio biográfico, análise retórica e bibliografía específica, Santiago de Compostela, Xunta de Galicia, 1996, I, págs. 329-30); “Hun cavaleyro, fi' de clerigon, / que non á en sa terra nulha ren, / [...] por tanto se non quer já conhocer / a quen sab' onde ven e onde non, / [...] por qué é tan oco, lhi non conven / contar quen sabe ond' est' e onde non / o seu barnagen e todo seu poder, / e faz, creent' a quantus aqui son / que val mui mays que non dev' a valer. / El sse quer muyt' a seu poder onrrar, / ca se quer por mays fidalgo meter / de quantus á en tod' aquel logar [...]" ("Hun cavaleyro, fi' de clerigón" -fragm.-, cantiga de Pedro Amigo de Sevilha, apud Mercedes Brea López, Lírica Profana Galego-Portuguesa..., II, págs. 751-2). 
material, duma linhagem ${ }^{17}$ e a sua rede clientelar, a qual à sua vez tem como suporte estrutural à linha primogênita ${ }^{18}$.

Um exemplo bem claro desta importância da casa também no âmbito da burguesia "enfidalgada" é o dos Cruu (família igualmente paradigmática em muitos outros aspectos). Comerciantes em origem, alcaldes e juízes na seguinte geração, acadam finalmente a fidalguia e de ai a regedoria perpétua em Pontevedra ${ }^{19}$, entroncados já com as famílias mais importantes da área (Arias de Aldao, Montenegro, Sarmiento). A sua primeira residência, situada na Rua das Travancas (freguesia de São Bartolomeu), mantenhe-na durante as duas primeiras gerações, nas que se movem (e casam) no âmbito dos mercadores. Na terceira geração, quando alcançam a fidalguia, dão à nova residencia familiar (na Rua de Dom Gonçalo) o aspeto "nobre" que agora se exigia, dotando-a de brasão, torre almeada e um arco que voava sobre a rua ${ }^{20}$.

f.2) o apelido como fator de coesão familiar e distintivo social.- Dado que o status da família é agora muito mais importante do que o de cada membro particular, toda identificação devém grupal $^{21}$; a manifestação principal disto, a

17 "Quero e he a miña voontade que toda a miña fazenda quede junta, porque sempre aja memoria das miñas casas e da miña gente fidalga que delas ben" (testamento de Pedro Árias de Aldao -1347-, apud María del Carmen Pallares MÉndez e Ermelindo Portela Silva, "Los mozos nobles...”, pág. 65).

18 Vítor Manuel Migués, As terras, as pousas e os vinculeiros. A fidalguía galega na Época Moderna, Sada, Do Castro, 2002, págs. 136-8; veja-se também Vítor Manuel Migués, “Entre la casa institucional y la casa residencial: imagen social y justificación simbólica de la hidalguía en Galicia”, Obradoiro de historia moderna, 14 (2005), págs. 201-23.

19 O esquema oligárquico percebe-se com absoluta claridade nesta cidade. Por uma parte, temos àquelas famílias da pequena e mediana nobreza muito urbanizadas e introduzidas no comércio (Montenegro, Arias de Aldao); pela outra, àquelas que seguiram o caminho inverso, do comercio à nobreza, como é o caso dos Falcom ou o dos próprios Cruu (José Armas CAstro, Pontevedra en los siglos XII a XV. Configuración y desarrollo de una villa marinera en la Galicia medieval, Pontevedra, Fundación Pedro Barrié de la Maza, 1992, págs. 207-9, 222-4, 236).

20 Segundo Armas Castro, Joám Cruu (quarta geração) casa com Inês Árias de Aldao, Pero Cruu (quinta geração) com Tareixa Sanches de Montenegro (neta de Tristám de Montenegro) e Gomes Cruu (o último da linhagem em época medieval) com Catarina Sarmiento (irmã de Garcia Sarmiento, senhor da casa de Sobroso) (José Armas CAStro, "Una familia de mercaderes pontevedreses...", págs. 128-9).

21 É por isto pelo que o retrato, entendido no senso moderno, resulta aqui funcionalmente supérfluo; "Heraldry indicated both selfhood and, more importantly, the bonds of blood and family alliance and affinity, which, unlike portraiture, belonged in the realm of the permanent" (Paul BINSKI, Medieval Death. Ritual and Representation, London, British Museum, 1996, pág. 105). Não podemos, pelo tanto, falar de verdadeiros "retratos" perante a escultura galega deste momento (Marta Cendón Fernández e María Dolores Barral Rivadulla, "Donantes y promotores: su imagen en la plástica gótica gallega”, Semata, 10 (1998), pág. 394). Com o que jogamos sempre, em todo caso, é com a identidade social, não com a individual. Na constelação formal-ideológica do homem baixomedieval, unicamente a condição (a posição na estrutura, digamos) é o que define a uma pessoa 
heráldica, cobra agora uma importância capital, e mais se temos em conta o predomínio absoluto neste momento da linguagem visual ${ }^{22}$. Ademais, a heráldica servirá também para se vincular com outras linhagens ${ }^{23}$.

f.3) a escultura funerária como veículo propagandístico.- Nenhuma manifestação, e disto eram conscientes estas personagens, pode igualá-lo poder da imagem do sepulcro como exibição pública e, sobre todo, duradoira, da sua posição de poder. As linhagens integrantes da nova nobreza trastamarista, como é o caso dos Andrade, Soutomaior, Ulhoa e Moscoso, sentiram cedo um forte desejo de emulá-los sepulcros suntuosos que já desde a segunda metade do século XIII deixaram de ser, em terras galegas, privilégio da família real e dos prelados, estendendo-se à alta nobreza e à hierarquia eclesiástica média ${ }^{24}$. A burguesia

aos olhos dos demais; se vemos só uma máscara é porque só podemos ver unha máscara, porque não há senão uma máscara, isto é, a posição social não é abstratizável da singularidade individual e vice-versa, pelo que o individuo só é em tanto que ocupa uma determinada posição ("How the dead were represented and what their effigies were made of, were thus in the first instance issues of group identity and not individuation: or rather, they were ways of presenting individuals only in so far as they were members of a group, eventually subsuming them to ideas of collective identity" -Paul Binski, Medieval Death..., pág. 102).

${ }^{22}$ Quando se chega às capas mais baixas da sociedade, nas que a conserva das estruturas parentelares é menos relevante em termos econômicos, os epígrafes funerários simplificam-se e unicamente informam do nome do finado, em ocasiões da sua condição social (no caso dos homens citando o seu ofício e no das mulheres ligando-as à figura do marido), e a data da morte (Marta Cendón FerNÁNDEZ e María Dolores BarRal Rivadulla, "Donantes y promotores...”, pág. 416). Em qualquer caso, "hay que tener en cuenta que la utilización de escudo no es en la Baja Edad Media exclusiva de los nobles [...]: oficios gremiales e incluso familias de marineros, pongamos por caso, suelen tener su escudo o su símbolo distintivo, convirtiendo el apellido en imagen parlante -un carballo por Carvallido, por ejemplo- o mezclando imágenes de herramientas de su oficio con símbolos cuantitativos [...], en un fenómeno que se extiende también por la costa portuguesa" (Alfredo Erias Martínez, "La conformación de una moda burguesa en la Galicia bajomedieval según la escultura funeraria", em Francisco Singul Lorenzo (coord.), Os capítulos da Irmandade. Peregrinación y conflicto social en la Galicia del siglo XV, Santiago de Compostela, Xunta de Galicia, 2006, pág. 153).

${ }^{23}$ Por exemplo, quando Vasco de Ulhoa diz no seu testamento "que se tena sempre por mais adiantado nome do meu linaje dulloa e o traiga no seu hescudo darmas co a Roda e pendon da señora Santa Catalina", o que pretende é somá-las armas dos Varela às suas (apud María del Carmen Pallares Méndez e Ermelindo Portela Silva, "Algunos problemas relativos a la evolución de las estructuras familiares en la nobleza", em María del Carmen Pallares Méndez e Ermelindo Portela Silva, De Galicia en la Edad Media. Sociedad, espacio y poder, Santiago de Compostela, Xunta de Galicia, 1993, pág. 264 -original em José Carlos Bermejo Barrera (coord.), Parentesco, familia y matrimonio en la historia de Galicia, Santiago de Compostela, Tórculo, 1989.

${ }^{24}$ Rocío SÁnchez AmeIJeIRas, El yacente armado en Galicia (1350-1450), memória de licenciatura inédita (dir.: S. Moralejo Álvarez), depositada na Biblioteca da Faculdade de Geografia e História da Universidade de Santiago de Compostela, Santiago de Compostela 1985, pág. 14. O exemplo de Paio Gomes Charinho, um dos primeiros nobres que tiveram o privilégio de soterramento numa capela mendicante (a capela maior de São Francisco de Pontevedra, financiada por ele por doação 
tomou boa nota e, parelho ao aumento do número de sepulcros baixo arcossólio e mesmo isentos no âmbito da nobreza, constatamos igualmente um aumento do número de laudas figuradas no da burguesia, essencialmente no deste setor poderoso de mercadores e notários ${ }^{25}$.

\section{Um exemplo Problemático: Moscoso e do Campo em São Domingos de BONAVAL}

Um caso certamente paradigmático desta fusão de burgueses enriquecidos e fidalgos urbanizados no seio das oligarquias municipais topamo-lo em Compostela, na relação entre as famílias do Campo e Moscoso e o seu panteão conjunto no mosteiro de Bonaval.

A dos do Campo era uma família burguesa adinheirada de Compostela, cidade na que contavam com um poder tanto civil (ao estarem introduzidos nos órgãos de governo municipal) como eclesiástico ${ }^{26}$. O seu centro de operações, e origem do seu patronímico, era a comercial Praça do Campo (popularmente do Pam, oficialmente de Cervantes ${ }^{27}$ ), cujo epicentro, junto às ruas do Caminho

post obitum no primeiro terço do século XIV), será seguido por muitos destes cavaleiros beneficiados após da contenda dinástica castelã; uma vez finalizada esta, 1375-1400, aparecem os primeiros exemplos de jacente armado, a um mesmo tempo em Compostela, Betanços e Riba d'Ávia; falamos dos sepulcros de Fernám Cao de Cordido (São Domingos de Bonaval; 1377-1399), Fernám Peres de Andrade (São Francisco de Betanços; 1387) e Lourenço Ares Loureiro (São Domingos de Riba d’Ávia; ca. 1390) (Rocío SÁNCHEZ AmEIJEIRAs, El yacente armado..., págs. 24-6).

${ }^{25}$ Pelo que respeita ao nível popular, as cousas seguem a discorrer pelo mesmo caminho; "La iglesia, su interior, es espacio de los muertos. Espacio preferido, buscado por muchos y concedido a los privilegiados, los clérigos de jerarquía más alta, los nobles, algunos burgueses, al menos en los lugares más importantes y con las formas más notables. No todas las iglesias son iguales; los clérigos, los nobles y los burgueses escogen. Los campesinos, no; en los contados casos de testamentos de campesinos de que hemos podido disponer, el lugar de enterramiento es siempre el cementerio de la iglesia parroquial" (María del Carmen Pallares Méndez e Ermelindo Portela Silva, "Los espacios de la muerte", em Manuel Núñez Rodríguez e Ermelindo Portela Silva (coords.), La idea y el sentimiento de la muerte en la historia y en el arte de la Edad Media II, Santiago de Compostela, Universidade de Santiago de Compostela, 1992, pág. 32).

${ }^{26}$ Ademais dos numerosos cônegos e arcediagos da família do Campo entre os séculos XIII e XV, (um outro) Joám do Campo, quem figurava como arcediago de Sárria desde 1316, fora promovido ao bispado de Cuenca em 1327, e logo aos de Oviedo (1328-1332) e León (1332-1344) (Eduardo Pardo de Guevara y Valdés, "Parentesco y nepotismo: los arzobispos de Santiago y sus vínculos familiares. Siglos XIV-XV”, em Ramón Yzquierdo Perrín (coord.), Los coros de catedrales y monasterios. Arte y liturgia, A Corunha, Fundación Pedro Barrié de la Maza, 2001, págs. 83-4, n. 77). Pela sua parte, a irmã do nosso Joám, Maria Vasques, foi esposa de Joám Nunes de Isorna e nai de Álvaro de Isorna, o futuro arcebispo (Eduardo PARDo DE Guevara y VaLdés, "Parentesco y nepotismo...”, pág. 82).

${ }^{27}$ Esta praça foi um dos primeiros espaços públicos especializados de Santiago. No século XII, o pregoeiro fazia ali públicos os acordos municipais e as ordenanças arcebispais, e a praça recebia 


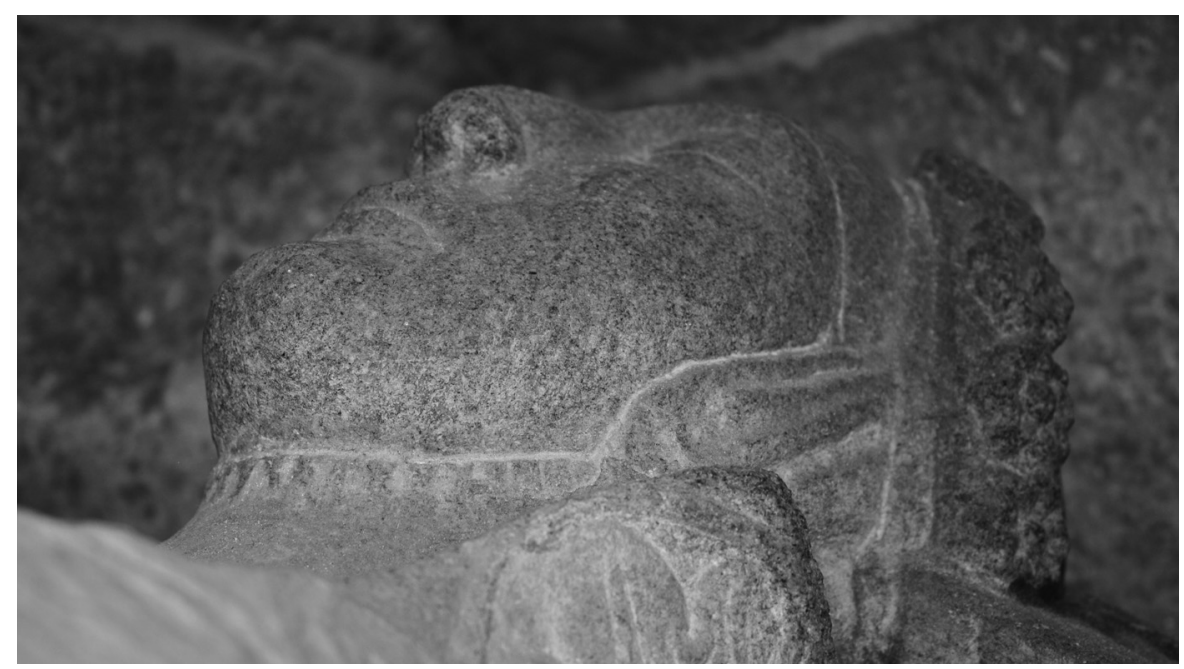

Fig. 3

Sepulcro de Maria de Moscoso (São Domingos de Bonaval, muro sul)

(hoje Casas Reais) e da Moeda (hoje Acibecheria), era nos séculos XIV e XV o núcleo de assentamento das elites burguesas de mercadores, notários e cambiadores, misturados com aqueles fidalgos introduzidos no comércio urbano, como era o caso dos Moscoso, proprietários das "casas grandes da Praça do Campo"28.

Os Moscoso cumprem aqui um papel igualmente prototípico. Integrantes da nova nobreza trastamarista, vivem o seu apogeu entre meados do século XIV e a centúria posterior. Desembarcam em Compostela por várias frontes: políticoeclesiástica (com dois arcebispos consecutivos, Alonso Sanches de Moscoso

a denominação de "Foro" (José Armas CASTro, "O afianzamento da realidade urbana despois do ano mil", em Ermelindo Portela Silva (coord.), Historia da cidade de Santiago de Compostela, Santiago de Compostela, Concello de Santiago de Compostela, Consorcio de Santiago, Universidade de Santiago de Compostela, 2003, pág. 90). Durante os séculos XIV e XV, o mais importante eixo de crescimento de Santiago era o que discorria entre a Porta do Caminho e a fachada norte da catedral, atravessando a Praça do Campo; ao longo deste percorrido, recebia diferentes nomes (Rua do Caminho, do Campo e da Moeda) e às vezes se designava conjuntamente na documentaçao como "Rua Maior". Nelas confluíam, ademais das ruas do setor mais setentrional e elevado (Algara de Cima e de Fondo -Algálias-, Prigna, Troia, da Pena, Valdedeus), as do eixo de Maçarelos (que começava na porta do mesmo nome e enlaçava as ruas da Mamoa -Orfas-, do Castro, dos Ferreiros -Caldeireria- e Preguntoiro) (José ARmas CASTRO, "O afianzamento da realidade urbana...", pág. 83). Progressivamente, o seu caráter comercial fora-se reforçando, e nela se exibiam os pesos e medidas oficiais pelos que se realizavam as transações comerciais na cidade (José ARMAS CASTRO, "O afianzamento da realidade urbana...", pág. 90).

${ }^{28}$ José Armas CAStro, “O afianzamento da realidade urbana...”, pág. 94. 


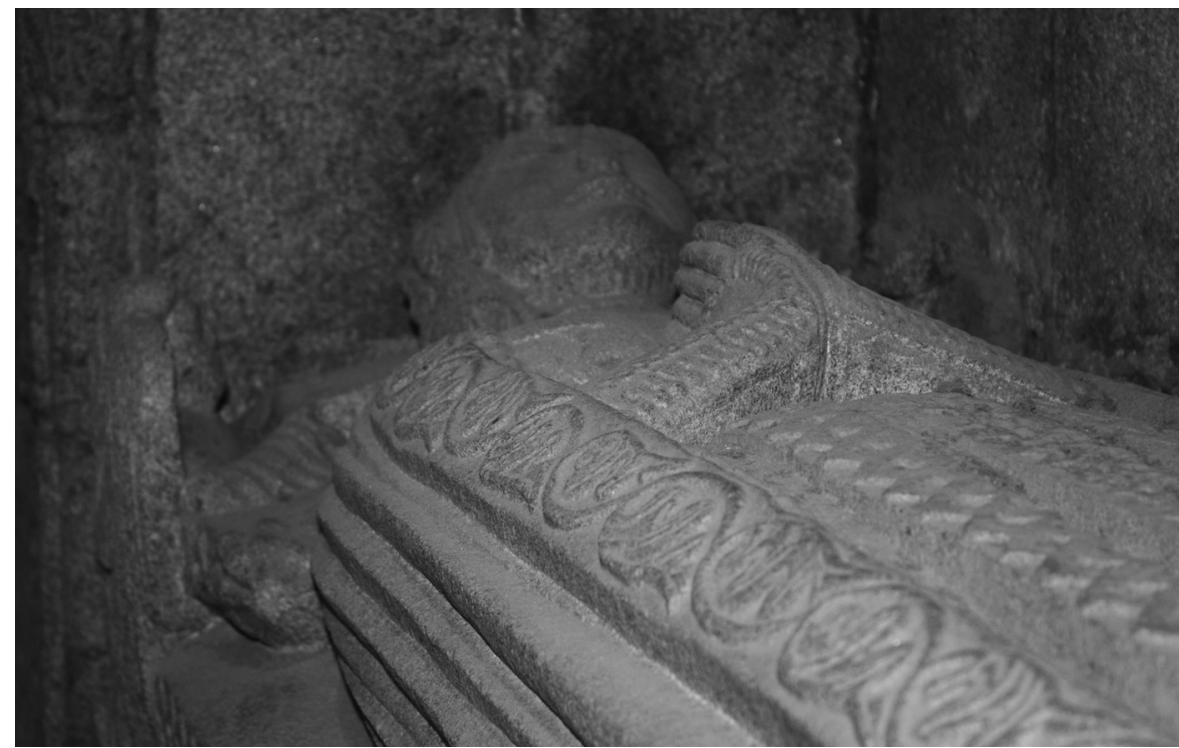

Fig. 4

Sepulcro Constança de Moscoso (São Domingos de Bonaval)

-1366-1367- e Rodrigo de Moscoso -1367-1382-), político-civil (monopolizando a pertigueiria maior de Santiago na segunda metade do século $X^{29}$ ) e econômica (graças aos seus vínculos com as famílias burguesas mais ricas, como os do Campo).

A aliança das duas famílias resultava beneficiosa para ambas. Por uma parte, os Moscoso acadavam um maior poder econômico e, consequentemente, político, no interior de Compostela; pela sua parte, os do Campo conseguiam o estatuto de fidalgos (com a consequente isenção tributária) e possibilidades de assentamento no exterior. Juntos, e dado que os Moscoso centravam o seu poder no núcleo de Casas Reais e os do Campo, como vimos, na praça homônima, asseguravam o controlo conjunto da área comercial compostelã, disposta ademais na entrada do Caminho Francês.

Esta aliança por coincidência de interesses recebe o seu selo simbólico apenas a umas dezenas de metros deste núcleo, no mosteiro de Bonaval. O primeiro episódio data de 1377, quando Joám do Campo, quem figura como alcalde em $1371^{30}$, adquire o padroado da sua capela maior, mercando duas laudas (“cam-

\footnotetext{
29 Eduardo Pardo de Guevara y Valdés, “Parentesco y nepotismo...”, pág. 75, n. 40.

30 Eduardo Pardo de Guevara y VAldés, "Parentesco y nepotismo...”, pág. 83.
} 
paas chaas") para ele e a sua dona, a ambos lados do coro ${ }^{31}$. Três anos depois, o seu testamento confirma o lugar de enterramento, do mesmo jeito que encarrega agora a lavra de dois monumentos com coberta chá ("moymento de cobritura chaa") ${ }^{32}$. O seguinte capítulo, no primeiro terço do século XV, vem da mão de Constança de Moscoso, herdeira do padroado e promotora das obra de reforma da capela, dos sepulcros e dos brasões que hoje vemos ${ }^{33}$.

Em relação com estes sepulcros, e a partires dum recente debate com motivo dum seminário de especialização ${ }^{34}$, propomos alguma modificação nas suas

31 "Por elles et por seus suçe- /sores que despoys delles veeren, damos et outorgamos a uos Iohan do Canpo, / cidadao de Santiago et vosa muler Costela [sic, por Constança] Meendez, duas sepulturas ontre os coros que esta na iglesia do dito moesteiro, onde os frayres do dito moesteiro / dizen as horas, huna sepultura na parte destra et outra na parte seestra, en que i estan / duas campaas chaas, et as cabeças das campaas que en teste en nos almari- / os en que see agora os liuros porque rezan as oras", apud Carmen MANSo PORTO, "El códice medieval del convento de Santo Domingo de Santiago (II)”, Archivo Dominicano, 4 (1983), pág. 81. Por outra parte, C. Manso considera que isto permitiria especular que para essa data, o 21 de Abril de 1377, a capela estaria já rematada (Carmen Manso Porto, Arte gótico en Galicia. Los dominicos, A Corunha, Fundación Pedro Barrié de la Maza, 1993, I, pág. 154).

32 "Eu Iohan do Canpo Breges [sic, por burguês] da çidade de Santiago, / fillo que foy de Fernan Garçia do Canpo [...] mando meu corpo soterrar no moesteiro de Santa Maria / de Bonavual, ontre os coros, hu os frayres disen as horas. Et que para min, façan huun / moymento de cobritura chaa, et ponnano aly hu os fraires seen ontre os coros, da / parte do coro destro, asy que o moimento seia asentado hu ora seen os seges do / coro destro do poyal. Et outro tal, no coro seestro para Constança Meendez", apud Carmen Manso Porto, "El códice medieval del convento de Santo Domingo de Santiago (I)”, Archivo Dominicano, 3 (1982), págs. 131-2. Joám falecerá ao mês seguinte de outorgá-lo testamento (Carmen Manso PorTo, Arte gótico en Galicia..., I, pág. 71).

33 Estas reformas teriam rematado cara 1419, quando Constança de Moscoso faz um donativo de objetos litúrgicos e uma fundação de quatro missas perpetuas na oitava de Ressurreição na capela maior, agás pelo que aos sepulcros respeita, que seriam posteriores (Carmen Manso Porto, Arte gótico em Galicia..., I, pág. 154). O seu fundamental papel topamo-lo referendado na carta de doação (1499) e no testamento (1500) de Lopo Sanches de Moscoso, primeiro conde de Altamira, quem se refere ademais à perpetuidade do padroado e ao cumprimento da obriga econômica (a pensão anual sobre as "casas do Campo") por parte dos seus sucessores segundo a disposição de Joám do Campo, a quem se refere como "tio" (ao tempo que a Constança como "tia", o que levou a Sánchez Ameijeiras a postular que Constança de Moscoso e Constança Meendez seriam a mesma mulher -Rocío SÁnchez AmeiJeIRAs, El yacente armado..., pág. 181-). Considera-se também que foi Constança de Moscoso quem rematou a igreja de Santa Maria do Azougue (Betanços), começada pelo que fora o seu esposo, Fernám Peres de Andrade; veja-se María Dolores Fraga SAmPEDRo, "El arte al servicio del "poderoso", em Marta Cendón Fernández, María Dolores Fraga Sampedro e María Dolores Barral Rivadulla, Arte y poder en la Galicia de los Trastámara: la provincia de La Coruña, Santiago de Compostela, Tórculo, 2000, págs. 158-9; Begoña Fernández RodríGUEz, "Aproximación a la cronología y al mecenazgo de un ejemplo brigantino: el templo de Santa María do Azougue”, Semata, 10 (1998), págs. 435-49.

34 "A memoria pétrea das mulleres con poder na Baixa Idade Media", impartido por Marta Cendón Fernández (USC) no marco do seminário de especialização do IEGPS Mulleres con poder ao final da Idade Media, o 13 de Julho de 2011. 


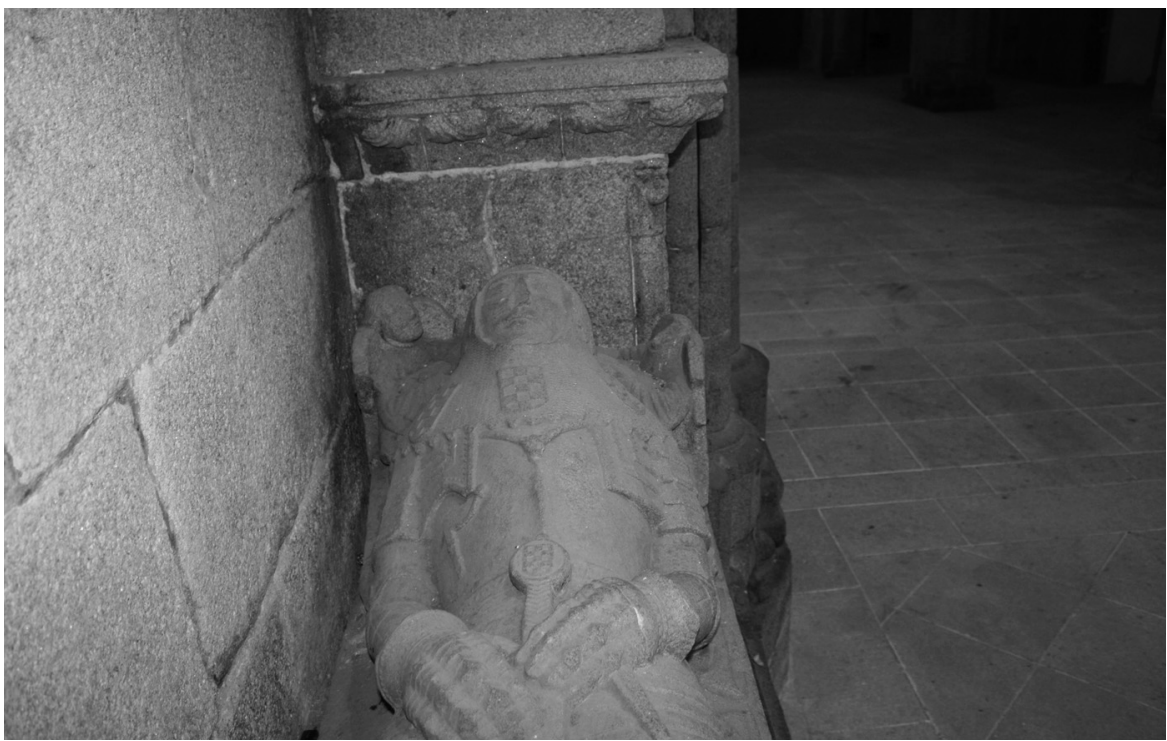

Fig. 5

Sepulcro de Joám do Campo (São Domingos de Bonaval)

atribuições. Assim, mentres que nos primeiros sepulcros dos lados norte e sul respetivamente, concordamos com as identificações de Sánchez Ameijeiras e Manso Porto (Constança de Moscoso $^{35}$ e Joám do Campo ${ }^{36}$ ), pelo que respeita

\footnotetext{
${ }^{35}$ Rocío SÁNCHEZ AmEIJEIRAS, "Actitudes ante la muerte en las mujeres de la nueva nobleza enriqueña: la escultura funeraria como fuente para la historia de las mentalidades”, em Ángela MuÑoz FERNÁNDEZ (ed.), Las mujeres en el cristianismo medieval. Imágenes teóricas y cauces de actuación religiosa, Madrid, Asociación Cultural Al-Mudayna, 1989, págs. 457-60; Carmen Manso PoRTO, Arte gótico en Galicia..., I, pág. 65. O frontal do seu sepulcro porta os escudos dos Moscoso - Moscoso - Andrade - Moscoso - Moscoso. Com anterioridade, identificou-se também com Teresa de Andrade (César VAamonde Lores, Gómez Pérez das Mariñas y sus descendientes. Apuntes históricos y genealógicos, A Corunha, Roel, 1917, págs. 105-6; Aureliano Pardo Villar, "Santo Domingo de Santiago (la construcción: la Capilla Mayor)", Cuadernos de Estudios Gallegos, 2 (1944-5), págs. 222-3; Manuel Chamoso Lamas, Escultura funeraria en Galicia: Orense, Pontevedra, Lugo, La Coruña, Santiago de Compostela, Ourense, Instituto de Estudios Orensanos Padre Feijoo, 1979, pág. 611).

36 Rocío Sánchez Ameijeiras, “Actitudes ante la muerte...”, págs. 457-60; Carmen Manso Porto, Arte gótico en Galicia..., I, pág. 65. O frontal do seu sepulcro porta cinco escudos dos Do Campo, os quais monopolizam igualmente o lenço mural no que se dispõe o seu sepulcro, aparecendo mesmo sobre do jacente. Com anterioridade, identificou-se também com Vasco Lopes de Ulhoa (Aureliano Pardo Villar, "Santo Domingo de Santiago...", pág. 222; Jesús María CaAmaño MarTínez, Contribución al estudio del gótico en Galicia. Diócesis de Santiago, Valladolid, Universidad de Valladolid, 1962, pág. 199; Manuel Cнамоso Lamas, Escultura funeraria..., pág. 607; Manuel NúÑEz RodríGuez, La idea de inmortalidad en la escultura gallega. La imaginería funeraria del
} 
aos do segundo tramo da capela maior consideramos que estes corresponderiam, respetivamente, aos de Maria de $\operatorname{Moscoso}^{37}$ no lado norte e (uma outra) Maria de $\mathrm{Moscoso}^{38}$ no sul.

\section{UM CAVALEIRO OU UM BURGUÊS? UM APONTE LACANIANO}

O sepulcro de Joám do Campo reclama agora a nossa atenção. Desde um punto de vista de crítica da ideologia, o primeiro passo será abandoná-la leitura simplista pela que este evidenciaria uma vontade de enobrecimento por parte de Joám de cara àqueles que o seu sepulcro pudessem ver. O primeiro cai pelo seu próprio peso, já que está documental e tipologicamente provado que corresponde a uma obra levada a cabo por Constança de Moscoso. Agora bem, esta vontade (de Constança, já que logo) tinha uma projeção pública (todo o "público" que podia ser um sepulcro como este, dado o reduzido número de pessoas que poderiam vê-lo) ou bem uma projeção cara à sua própria extração social, a sua classe?

A problemática que aqui se apresenta amossa uma forte homologia formal com a parelha lacaniana de identificação imaginária e simbólica, $i(o)$ e $I(O)^{39}$. A lógica

caballero, s. XIV-XV, Ourense, Deputación Provincial de Ourense, 1985, pág. 16). Uma outra possibilidade, também plausível, seria que se tratasse de Bernal Eáns do Campo.

37 O frontal do seu sepulcro porta os escudos dos Moscoso - Moscoso - Mesia - Moscoso - Moscoso, o que viria justificado pelo feito de levar no centro, como sucede nestes casos, o escudo do seu marido (Maria estava casada com Gonçalo Dias de Mesia, de feito é a única mulher da linhagem Moscoso casada com um Mesia, família a quem indubitavelmente pertence este escudo). Com anterioridade, identificou-se também com Maior Fernandes de Moscoso (Rocío Sánchez AmeIJeIRAS, “Actitudes ante la muerte...”, págs. 457-60; Carmen Manso Porto, Arte gótico en Galicia..., I, pág. 65) e com Joana de Castro ou de Lara (Aureliano Pardo Villar, "Santo Domingo de Santiago...", pág. 224; Jesús María CaAmaño Martínez, Contribución..., pág. 200; Manuel Chamoso Lamas, Escultura funeraria..., pág. 613; Manuel NúÑEz Rodríguez, La idea de inmortalidad..., pág. 16).

38 O frontal do seu sepulcro porta os escudos dos Moscoso - do Campo - Andrade - Moscoso - do Campo, isto é, aos lados os escudos da sua família (o seu pai era Joám Bezerra de Cances, à sua vez filho de Martinho Bezerra de Cances e Urraca Rodrigues do Campo) e, no centro, o do seu marido, Fernám Peres de Andrade II ( $† 1470)$. Com anterioridade, identificou-se também com a própria Urraca Rodrigues do Campo (Carmen Manso Porto, Arte gótico en Galicia..., I, pág. 65), com uma suposta filha de Constança de Moscoso / Meendez (Rocío SÁnchez AmeIJeIRas, "Actitudes ante la muerte...", págs. 457-60), e mais com Inês de Moscoso (Aureliano Pardo VIlLar, "Santo Domingo de Santiago...”, pág. 222; Jesús María CAamaño Martínez, Contribución..., pág. 200; Manuel Chamoso Lamas, Escultura funeraria..., pág. 609; Manuel NúÑEz Rodríguez, La idea de inmortalidad..., pág. 16).

39 Sobre o particular, veja-se Jacques LACAN, "Subversion du sujet et dialectique du désir dans l'inconscient freudien", em Jacques Lacan, Écrits, Paris, Seuil, 1966, págs. 793-827; Jacques LACAN, Le Séminaire de Jacques Lacan (texte établi par Jacques-Alain Miller). Livre V: Les formations de l'inconscient, Paris, Seuil, 1998 (1957-8); Jacques-Alain MilLer, "Les réponses du réel", em PaulLaurent Assoun (ed.), Aspects du malaise dans la civilisation, Paris, Navarion, 1987, págs. 9-22. Se- 
diferencial entre a primeira (a do eu ideal, Idealich) e a segunda (a do ideal do eu, Ich-Ideal), obviamente simplificada, é a que separa o como nos vemos a nós mesmos e o ponto desde o que somos observados. A interação dos próprios níveis imaginário e simbólico baixo do domínio da $I(O)$ constitui o mecanismo pelo que o sujeito é integrado a um campo sócio-simbólico dado, posto que (de feito já ao nível da identificação imaginária) a identificação dá-se sempre em nome duma certa mirada no Outro (a estrutura-Outro do primeiro Deleuze, por outra parte). É dizer, a propósito de cada rol, a pregunta será: para quem atua o sujeito este papel? Que mirada tem em conta o sujeito quando se identifica com uma determinada imagem ${ }^{40}$

guindo com estas homologias (insistimos, formais) lacanianas, este sepulcro não responde igualmente à lógica do "ponto nodal" [point de capiton]? O espaço ideológico compõe-se de elementos ilhados, não relacionados e de identidade "aberta" ("significantes flotantes", diria Laclau), sobre-determinados pela sua articulação relacional a partir deste ponto/conceito/objecto que os totaliza e fixa os seus significados (fazendo assim parte da rede do significado); veja-se Jacques LaCAN, Le Séminaire de Jacques Lacan (texte établi par Jacques-Alain Miller), Livre III: Les psychoses, Paris, Seuil, 1981 (1955-6). Já que logo, este point de capiton "[...] is the element which represents the agency of the signifier within the field of the signified. In itself it is nothing but a 'pure difference': its role is purely structural, its nature is purely performative -its signification coincides with its own act of enunciation; in short, it is a 'signifier without the signified'. The crucial step in the analysis of an ideological edifice is thus to detect, behind the dazzling splendour of the element which holds it together [...], this self-referential, tautological, performative operation" (Slavoj Žı̌̌̌K, The Sublime Object of Ideology, London / New York, Verso, 2008 (1989), pág. 109). Poderíamos dizer que, ao nível da comunicação simbólica, o sepulcro funciona, usando o célebre termo de Kripke, como uma sorte de "designante rígido" e, como aponta Žižek, "the analysis of ideology must [...] direct its attention to the points at which names which prima facie signify positive descriptive features already functions as 'rigid designators"” (Slavoj ŽižEK, Sublime Object..., pág. 121). O elemento fundamental é sempre essa instância paradoxal, cujo papel é interpretado aqui pelo sepulcro, que circula entre o significante e o significado sem que poda ser reduzido a nenhum deles, sendo o espelho que assegura a sua comunicação; "Si les termes de chaque série sont relativement déplacés, les uns par rapport aux autres, c'est parce qu'ils ont d'abord en eux mêmes une place absolue, mais que cette place absolue se trouve toujours déterminée par leur distance à cet élément qui ne cesse de se déplacer par rapport à soi dans les deux séries" (Gilles Deleuze, Logique du sens..., pág. 55). É por todo isto pelo que o seu funcionamento é homologável ao do fetiche que, sobre da base da teoría freudiana da isolierung, Mannoni sintetizava na fórmula "Je sais bien, mais quand même..." (a lógica pela que um pode crer numa fantasia ao mesmo tempo que sabe -se bem não o interioriza a nível afetivo- que não é mais que uma fantasia -por outra parte, esta é a mesma lógica pela que a ideologia funciona-; veja-se Octave MANNonI, "Je sais bien, mais quand même...", em Octave Mannoni, Clefs pour l'imaginaire ou L'Autre Scène, Paris, Seuil, 1969, págs. 9-33).

${ }^{40}$ Slavoj Žı̌̌̌K, Sublime Object..., págs. 117-8. De prestarem atenção à mirada desde a que uma determinada identificação constitui ao sujeito, e perante as representações desta burguesia enriquecida, do que teríamos que falar é dum fenômeno de "legitimação"; "Legitimation refers to the process by which a ruling power comes to secure from its subjects an at least tacit consent to its authority [...]. To legitimate one's power is not necessarily to 'naturalize' it, in the sense of making it appear spontaneous and inevitable to one's subordinates: a group or class may well perceive that there could be kinds of authority other than that of their masters, bur endorse this authority even so. A mode of domination is generally legitimated when those subjected to it come to judge their own behaviour by the criteria of their rulers" (Terry EAGLETON, Ideology..., págs. 54-5; a cursiva é nossa). 
Constança está a buscar que a imagem de Joám ocupe um lugar determinado na rede simbólica intersubjetiva, derivando em certo modo, se se nos permite, a própria $i(o)$ da linhagem Moscoso cara a sua $I(O)^{41}$, toda vez que assume este mandato estrutural ${ }^{42}$. E dado que toda $i(o)$ representa um ser-para-outro, que devêm ser-para-sim uma vez se assume simbolicamente (é dizer, estruturalmente) a identificação com a mirada para a que se interpreta esse determinado papel $^{43}$, não resulta pelo tanto evidente que esta operação é, de todo ponto, de clase, interna ${ }^{44}$

\section{IT'S THE ECONOMY, ...! UMA PEQUENA EXTRAPOLAÇÃO}

Exemplos como estes, a pouco que se repare neles, abrem aginha as portas a considerações ideológicas mais gerais. Com o uso de conceitos como o da para-

${ }^{41}$ De certo, já "the first name designates the ideal ego, the point of imaginary identification, while the family name comes from the father -it designates, as the Name-of-the-Father, the point of symbolic identification, the agency through which we observe and judge ourselves. The fact that should not be overlooked in this distinction is that $\mathrm{i}(\mathrm{o})$ is always already subordinated to $\mathrm{I}(\mathrm{O})$ : it is the symbolic identification (the point from which we are observed) which dominates and determines the image, the imaginary form in which we appear to ourselves likeable" (Slavoj ŽžžE, Sublime Object..., pág. 120).

${ }^{42}$ Sem que por isso seja completamente "falso", ou se rompa com "decoro" algum, no senso de que, ao igual que o próprio Joám pedira ser soterrado num primeiro momento numa "campaa chaa" e posteriormente num "moymento de cobritura chaa", como correspondia ao seu "estado", uma vez as duas famílias se misturam e a fidalga Constança reforma a capela e manda construí-los novos sepulcros, de certo para ela os quatro membros do grupo familiar estariam já numa mesma situação (Joám estaria para ela inter pares). Em todo caso, como já dissemos, a nível ideológico a "verdade" do contido afirmado é irrelevante; "Le mythe est une valeur, il n'a pas la vérité pour sanction: rien ne l'empêche d'être un alibi perpétuel: il lui suffit que son signifiant ait deux faces pour disposer toujours d'un ailleurs: le sens est toujours là pour présenter la forme; la forme est toujours là pour distancer le sens. Et il n'y a jamais contradiction, conflit, éclatement entre le sens et la forme: ils ne se trouvent jamais dans le même point" (Roland BARTHES, Mythologies, Paris, Seuil, 1970 -1957-, pág. 196).

43 "This gap between the way I see myself and the point from which I am being observed to appear likeable to myself is crucial for grasping hysteria [...] -for so-called hysterical theatre: when we take the hysterical woman in the act of such a theatrical outburst, $[\ldots]$ concrete analysis has to discover who [...] embodies for her the Other. Behind an extremely 'feminine' imaginary figure, we can thus generally discover some kind of masculine, paternal identification: she is enacting fragile femininity, but on the symbolic level she is in fact identified with the paternal gaze, to which she wants to appear likeable. This gap is brought to its extreme with the obsessional neurotic: on the 'constituted', imaginary, phenomenal level he is of course caught in the masochistic logic of his compulsive acts, he is humiliating himself, preventing his success, organizing his failure, and so on; but the crucial question is again how to locate the vicious, superego gaze for which he is humiliating himself, for which this obsessional organizing of failure procures pleasure" (Slavoj Žı̌̌EK, Sublime Object..., pág. 118).

${ }^{44}$ Ademais, tenhamos de novo em conta o muito reduzido número de pessoas que na época poderiam contemplá-los sepulcros da capela. 
laxe ${ }^{45}$ perante estas estruturas simbólicas (anamórficas em relação a um mesmo núcleo traumático, o Real), perante os determinantes econômicos e os parâmetros representativos, vemos como por detrás dos câmbios aparentes que operam nestes dois séculos com os que a Idade Media chega ao seu fim, em termos reais (isto é, econômicos) apenas mudou nada.

As pardas folhas do outono medieval estão a piques de cair, se é que não começaram já ao fazer. Momentos como este, o epílogo dum determinado "periodo", incitaram sempre aos historiadores a observar quantidade inúmera de câmbios, com independência da sua relevância ou ainda impacto real. No caso baixo-medieval, o ascenso da burguesia e o comércio $^{46}$, a aceleração consequente do uso da moeda e a incipiente instabilidade da fidalguia, levaram a muitos a convocar um termo quanto menos específico: "capitalismo".

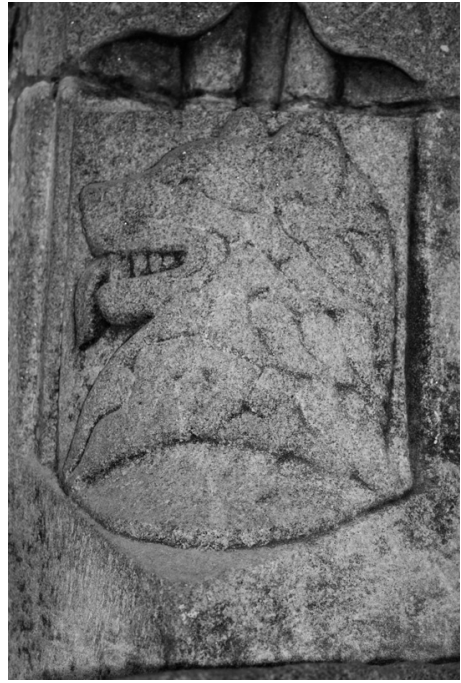

Fig. 6

Escudo dos Moscoso no arcossólio do sepulcro de Maria de Moscoso (São Domingos de Bonaval, muro norte)

Porém, tal análise resulta superficial e, em última instância, errônea. Não existe base argumental para pressupor um caráter de necessidade recíproca entre este auge comercial e um suposto câmbio nas relações de produção. As estruturas de poder não mudaram (seguem essencialmente nas mãos da aristocracia territorial), como também não as dinâmicas de propriedade e, sobre todo, as relações de produção de tipo feudal. Galiza é senhorial agora e seguirá a sê-lo durante muito tempo ainda ${ }^{47}$. Os discursos, representações, ideologias em último termo,

\footnotetext{
45 Pelo comum, a paralaxe é definida como a deslocação aparente dum objeto por mor dum câmbio na posição de observação. A partires deste conceito, Žižek desenvolveu toda uma teoria da mediação e da fenda de paralaxe como enfrontamento de perspetivas estreitamente vinculadas mais entre as que não existe espaço compartido, campo neutral, ao jeito da cinta de Moebius; veja-se Slavoj Žıžek, The Parallax View, Cambridge / London, MIT, 2006; Matías García RodríGuez, "Classe, representaçom e paralaxe nos sepulcros da capela maior de Sam Domingos de Bonaval", em prensa.

${ }^{46}$ Terry Eagleton tem afirmado em mais duma ocasião, de jeito irônico (e sem falta de razão), que resulta difícil topar um manual de história europeia, sobre a época que seja, na que esta não venha caraterizada como um período de transição, marcada por rápidos câmbios e um ascenso das classes médias.

${ }^{47}$ A desintegração do modo de produção feudal dependerá das suas próprias contradições internas. Nem o comércio nem a mera acumulação de dinheiro podem mudá-lo, já que este capital comercial
} 
que temos visto no âmbito da burguesia enriquecida (e as ideologias dependem sempre da estrutura produtiva $\left.{ }^{48}\right)$, venhem a testemunhar este continuísmo.

é tão só capital circulante, e unicamente quando se faga cargo da produção, subordinando-se assim ao capital industrial, poderemos falar dum "modo de produção capitalista", e não antes.

${ }^{48} \mathrm{Se}$ bem os seus ataques à deriva culturalista da crítica marxista vão as mais das vezes demasiado longe no seu reducionismo economicista, as teses de Abercrombie, Hill e Turner resultam muito interessantes (e a miúdo são irrefutáveis em termos de causalidade histórica). Como eles analisam, o papel da ideologia no feudalismo é apenas o dum suplemento necessário do modo de produção, a sua legitimação discursiva e não a sua base causal. O papel aqui da Igreja, já que logo, foi duplo: por uma parte, legitimava o sistema econômico e, pela outra, unificava às classes dominantes em torno a um sistema comum de crenças e rituais (o modo de produção feudal não precisava, de feito, dum sistema ideológico que integrasse realmente aos trabalhadores, dado que estes estavam já coercitados não por discursos, senão pelas relações de propriedade, a violência senhorial, a fome, a existência de núcleos populacionais pequenos e ilhados, etc.). Assim, por exemplo, a sua doutrina sexual servia de justificação à dominação patriarcal (a mulher era uma mercadoria a nível de alianças), a doutrina familiar e matrimonial respaldava um sistema estável de herdança via matrimônios e primogenitura masculina que garantia a concentração e conservação da propriedade em mãos das famílias nobres, a mistificação da cavaleiria permitia unificá-la rama eclesiástica e secular-militar das classes dominantes, etc. (o papel da Igreja é aqui o do mecanismo ideológico básico, fazer aparecê-lo contingente como necessário, "natural"); veja-se Nicholas ABERCROMBIE, Stephen Hill e Bryan Turner, The Dominant Ideology Thesis, London, Routledge, 1980. Por esta razão precisa, resultam erradas aquelas historiografias baseadas no tão manido e, de por sim, vago e reconciliador conceito da "mentalidade" ("[...] ideologies are not made up of 'ideas' but of practices [...] Ideology does not reproduce itself in the general form of a Zeitgeist (i.e. the spirit of the age, the 'mentality' of an epoch, 'habits of thought', etc.) imposed in an even and homogeneous way on 'society' as a kind of space pre-existing class struggle" -Michel PÊCHEUX, "The Mechanism of Ideological (Mis)recognition...", pág. 142-). "La muerte, no cabe la menor duda, es un tema serio. En manos de los historiadores, es, además, un tema peligroso. Queremos decir, expuesto, sobre todo, al peligro de una literatura fácil -teñida habitualmente, claro está de dramatismo-, apoyada en la descripción de comportamientos, de creencias, de ritos y de escenas fúnebres. La llamada historia de la muerte, si pretende, como creemos que debe, escapar de ese espacio restringido, es una historia difícil de hacer" (María del Carmen Pallares Méndez e Ermelindo Portela SILVA, "Muerte y sociedad en la Galicia medieval (ss. XII-XIV)", em Manuel Núñez Rodríguez e Ermelindo Portela Silva (coords.), La idea y el sentimiento de la muerte en la historia y en el arte de la Edad Media, Santiago de Compostela, Universidade de Santiago de Compostela, 1988, pág. 21). Uma vez levantados os pés das relações de produção e dos contextos concretos, e tanto mais quando falamos de arte, resulta singelo fazer extrapolações a problemas cuja repercussão na Galiza fica ainda indemonstrada, ou mesmo cuja falsidade quedou já provada (por exemplo a questão do purgatório, de cuja ressonância no Baixo Medievo galego ainda não apareceu testemunho algum; veja-se José Miguel AndRade Cernadas, "Los testamentos como reflejo de los cambios actitud ante la muerte en la Galicia del siglo XIV”, Semata, 17 (2006), pág. 101). Mistificados, moralizados e individualizados, os problemas ficam indefinidos; um exemplo disto é o representado por, entre outros, Manuel NúÑEz Rodríguez, La idea de inmortalidad...; "El caballero, la muerte y la fama póstuma”, em Leopoldo Balboa López e Herminia Pernas Oroza (coords.), Entre nós. Estudios de Arte, Xeografía e Historia en homenaxe ó profesor Xosé Manuel Pose Antelo, Santiago de Compostela, Universidade de Santiago de Compostela, 2001, págs. 29-47. 


\section{CONCLUSÕES}

A história da morte, como dizem os professores Pallares e Portela, é sem dúvida uma história difícil de fazer. A história da arte da morte da Idade Média (se bem, como vimos, é uma arte que mira de jeito obsceno cara o mundo dos vivos), tampouco é singela de levar a cabo (e mais no que se refere a estes séculos finais, tantas vezes abandonados à sua sorte). Faltam fontes, ademais, muitas fontes e, porém, esta história começou-se há tempo a escrever; em todo caso, ainda é muito o que resta por fazer, e a crítica da ideologia é uma metodologia plausível e, como se têm demostrado noutras muitas disciplinas, ainda com um grande futuro. O relato de cavaleria, o álbum de iconografia, a recreação dum Zeitgeist pré-fabricado ou um já desdentado formalismo não são já caminhos praticáveis.

Em relação com o exemplo escolhido nesta ocasião, os sepulcros da capela maior de Bonaval, baseamos a nossa leitura numas atribuições que, ainda não concordando na sua totalidade com elas, devem muitos dos seus argumentos a Sánchez Ameijeiras e Manso Porto, responsáveis de romper com o continuísmo derivado da identificação do sepulcro do cavaleiro com o de Vasco Lopes de Ulhoa, que se remontava a López Ferreiro e que fora majoritariamente seguida (ou, de jeito mais preciso, repetida). Esperamos ter aportado algum argumento que reforce as nossas atribuições, quanto menos pelo que respeita aos discursos, conscientes ou inconscientes, que sustenhem estas representações.

\section{BIBLIOGRAFIA}

Abercrombie, Nicholas, Hill, Stephen e Turner, Bryan, The Dominant Ideology Thesis, London, Routledge, 1980.

Althusser, Louis, "Ideology and Ideological State Apparatuses (Notes towards na Investigation)", em Žižek, Slavoj (ed.), Mapping Ideology, London / New York, Verso, 1994 (1970 para esta tradução), págs. 100-40 (original em Althusser, Louis, "Ideologie et appareils idéologiques d'État (notes pour une recherche)", em La Pensée, 151 -1970-).

Andrade Cernadas, José Miguel, "Los testamentos como reflejo de los cambios actitud ante la muerte en la Galicia del siglo XIV”, Semata, 17 (2006), págs. 97-114.

Andrade Cernadas, José Miguel e Pérez Rodríguez, Francisco Javier, Galicia Medieval, t. III de Historia de Galicia, Oleiros, Vía Láctea, 1995.

Armas Castro, José, "Una familia de mercaderes pontevedreses a finales de la Edad Media: los Cruu", Cuadernos de Estudios Gallegos, 101 (1986), págs. 117-32.

Armas Castro, José, Pontevedra en los siglos XII a XV. Configuración y desarrollo de una villa marinera en la Galicia medieval, Pontevedra, Fundación Barrié de la Maza, 1992. 
Armas Castro, José, "O afianzamento da realidade urbana despois do ano mil", em Portela Silva, Ermelindo (coord.), Historia da cidade de Santiago de Compostela, Santiago de Compostela, Concello de Santiago de Compostela, Consorcio de Santiago, Universidade de Santiago de Compostela, 2003, págs. 79-121.

Barthes, Roland, Mythologies, Paris, Seuil, 1970 (1957).

Barthes, Roland, Roland Barthes by Roland Barthes, tr. por Richard Howard, Berkeley, California University Press, 1994 (1975).

Beceiro Pita, Isabel e Córdoba de la Llave, Ricardo, Parentesco, poder y mentalidad. La nobleza castellana siglos XII-XV, Madrid, CSIC, 1990.

Binski, Paul, Medieval Death. Ritual and Representation, London, British Museum, 1996.

Brea López, Mercedes (coord.), Lírica Profana Galego-Portuguesa. Corpus completo das cantigas medievais, con estudio biográfico, análise retórica e bibliografía específica, Santiago de Compostela, Xunta de Galicia, 1996, 2 v.

Caamaño Martínez, Jesús María, Contribución al estudio del gótico en Galicia. Diócesis de Santiago, Valladolid, Universidad de Valladolid, 1962.

Chamoso Lamas, Manuel, Escultura funeraria en Galicia: Orense, Pontevedra, Lugo, La Coruña, Santiago de Compostela, Ourense, Instituto de Estudios Orensanos Padre Feijoo, 1979.

Cendón Fernández, Marta e Barral Rivadulla, María Dolores, "Donantes y promotores: su imagen en la plástica gótica gallega”, Semata, 10 (1998), págs. 389-420.

Deleuze, Gilles, Différence et répétition, Paris, Pág.U.F., (1969).

Deleuze, Gilles, Logique du sens, Paris, Minuit, 1969.

Deleuze, Gilles, Critique et clinique, Paris, Minuit, 1993.

Ducrot, Oswald, Le dire et le dit, Paris, Minuit, 1980.

Eagleton, Terry, Ideology. An Introduction, London / New York, Verso, 1998 (1991).

Erias Martínez, Alfredo, "La conformación de una moda burguesa en la Galicia bajomedieval según la escultura funeraria”, em Singul Lorenzo, Francisco (coord.), Os capítulos da Irmandade. Peregrinación y conflicto social en la Galicia del siglo XV, Santiago de Compostela, Xunta de Galicia, 2006, págs. 152-67.

Fernández Rodríguez, Begoña, “Aproximación a la cronología y al mecenazgo de un ejemplo brigantino: el templo de Santa María do Azougue”, Semata, 10 (1998), págs. 435-49.

Fraga Sampedro, María Dolores, "El arte al servicio del 'poderoso"”, em Cendón Fernández, Marta, Fraga Sampedro, María Dolores e Barral Rivadulla, María Dolores, Arte y poder en la Galicia de los Trastámara: la provincia de La Coruña, Santiago de Compostela, Tórculo, 2000, págs. 115-72.

García Rodríguez, Matías, "Classe, representaçom e paralaxe nos sepulcros da capela maior de Sam Domingos de Bonaval”, em prensa.

Lacan, Jacques, "Subversion du sujet et dialectique du désir dans l'inconscient freudien", em Lacan, Jacques, Écrits, Paris, Seuil, 1966, págs. 793-827.

Lacan, Jacques, Le Séminaire de Jacques Lacan (texte établi par Jacques-Alain Miller), Livre III: Les psychoses, Paris, Seuil, 1981 (1955-6).

Lacan, Jacques, Le Séminaire de Jacques Lacan (texte établi par Jacques-Alain Miller), Livre V: Les formations de l'inconscient, Paris, Seuil, 1998 (1957-8). 
López Carreira, Anselmo, A cidade de Ourense no século XV. Sociedade urbana na Galicia baixomedieval, Ourense, Deputación Provincial de Ourense, 1998.

Mannoni, Octave, "Je sais bien, mais quand même...", em Mannoni, Octave, Clefs pour l'imaginaire ou L'Autre Scène, Paris, Seuil, 1969, págs. 9-33.

Manso Porto, Carmen, "El códice medieval del convento de Santo Domingo de Santiago (I)", Archivo Dominicano, 3 (1982), págs. 117-64.

Manso Porto, Carmen, "El códice medieval del convento de Santo Domingo de Santiago (II)", Archivo Dominicano, 4 (1983), págs. 75-129.

Manso Porto, Carmen, Arte gótico en Galicia. Los dominicos, A Corunha, Fundación Pedro Barrié de la Maza, 1993, 2 v.

Migués, Vítor Manuel, As terras, as pousas e os vinculeiros. A fidalguía galega na Época Moderna, Sada, Do Castro, 2002.

Migués, Vítor Manuel, "Entre la casa institucional y la casa residencial: imagen social y justificación simbólica de la hidalguía en Galicia”, Obradoiro de historia moderna, 14 (2005), págs. 201-23.

Miller, Jacques-Alain, "Les réponses du réel", em Assoun, Paul-Laurent (ed.), Aspects $d u$ malaise dans la civilisation, Paris, Navarin, 1987, págs. 9-22.

Núñez Rodríguez, Manuel, La idea de inmortalidad en la escultura gallega. La imaginería funeraria del caballero, s. XIV-XV, Ourense, Deputación Provincial de Ourense, 1985.

Núñez Rodríguez, Manuel, "El caballero, la muerte y la fama póstuma”, em Balboa López , Leopoldo e Pernas Oroza, Herminia (coords.), Entre nós. Estudios de arte, xeografía e historia en homenaxe ó profesor Xosé Manuel Pose Antelo, Santiago de Compostela, Universidade de Santiago de Compostela, 2001, págs. 29-47.

Pallares Méndez, María del Carmen, A vida das mulleres na Galicia Medieval (1100-1500), Santiago de Compostela, Universidade de Santiago de Compostela, 1993.

Pallares Méndez, María del Carmen e Portela Silva, Ermelindo, "Muerte y sociedad en la Galicia medieval (ss. XII-XIV)", em Núñez Rodríguez, Manuel e Portela Silva, Ermelindo -coords.-, La idea y el sentimiento de la muerte en la historia y en el arte de la Edad Media, Santiago de Compostela, Universidade de Santiago de Compostela, 1988, págs. 9-19.

Pallares Méndez, María del Carmen e Portela Silva, Ermelindo, "Los espacios de la muerte", em Núñez Rodríguez, Manuel e Portela Silva, Ermelindo (coords.), La idea y el sentimiento de la muerte en la historia y en el arte de la Edad Media II, Santiago de Compostela, Universidade de Santiago de Compostela, 1992, págs. 27-34.

Pallares Méndez, María del Carmen e Portela Silva, Ermelindo, "Algunos problemas relativos a la evolución de las estructuras familiares en la nobleza", em Pallares Méndez, María del Carmen e Portela Silva, Ermelindo, De Galicia en la Edad Media. Sociedad, espacio y poder, Santiago de Compostela, Xunta de Galicia, 1993 (original em Bermejo Barrera, José Carlos (coord.), Parentesco, familia y matrimonio en la historia de Galicia, Santiago de Compostela, Tórculo, 1989).

Pallares Méndez, María del Carmen e Portela Silva, Ermelindo, "Los mozos nobles: grandes hombres, si fueran hijos solos", Revista d'historia medieval, 5 (1994), págs. 55-74.

Pallares Méndez, María del Carmen e Portela Silva, Ermelindo, $O$ encadramento social e a loita polo poder, em Barreiro Fernández, Xosé Ramón e Villares Paz, Ramón (coords.), A 
Gran Historia de Galicia, A Corunha, 2007, t. V, De Xelmírez aos Irmandiños. A Galicia feudal (séculos XII-XV), vol. 2.

Pardo de Guevara y Valdés, Eduardo, "Parentesco y nepotismo: los arzobispos de Santiago y sus vínculos familiares. Siglos XIV-XV", em Yzquierdo Perrín, Ramón (coord.), Los coros de catedrales y monasterios. Arte y liturgia, A Corunha, Fundación Pedro Barrié de la Maza, 2001, págs. 63-119.

Pardo de Guevara y Valdés, Eduardo, "De las viejas estirpes a las nuevas hidalguías: el entramado nobiliario gallego al fin de la Edad Media”, Nalgures, 3 (2006), págs. 263-78.

Pardo Villar, Aureliano, "Santo Domingo de Santiago (la construcción: la Capilla Mayor)", Cuadernos de Estudios Gallegos, 2 (1944-5), págs. 203-26.

Pêcheux, Michel, “The Mechanism of Ideological (Mis)recognition”, em Žižek, Slavoj, (ed.), Mapping Ideology, London / New York, Verso, 1994, págs. 141-51 (original em Pêcheux, Michel, Les vérités de La Palice. Linguistique, sémantique, philosophie, Paris, Maspero, 1975).

Sánchez Ameijeiras, Rocío, El yacente armado en Galicia (1350-1450), memória de licenciatura inédita (dir.: S. Moralejo Álvarez), depositada na Biblioteca da Faculdade de Geografia e História da Universidade de Santiago de Compostela, Santiago de Compostela, 1985.

Sánchez Ameijeiras, Rocío, “Actitudes ante la muerte en las mujeres de la nueva nobleza enriqueña: la escultura funeraria como fuente para la historia de las mentalidades", em Muñoz Fernández, Ángela (ed.), Las mujeres en el cristianismo medieval. Imágenes teóricas y cauces de actuación religiosa, Madrid, Asociación Cultural Al-Mudayna, 1989, págs. 451-61.

Vaamonde Lores, César, Gómez Pérez das Mariñas y sus descendientes. Apuntes históricos y genealógicos, A Corunha, Roel, 1917.

Žižek, Slavoj, The Sublime Object of Ideology, London / New York, Verso, 2008 (1989).

Žižek, Slavoj, “The Spectre of Ideology”, em Žižek, Slavoj (ed.), Mapping Ideology, London / New York, Verso, 1994, págs. 1-33.

Žižek, Slavoj, The Parallax View, Cambridge / London, MIT, 2006. 